DOI https://doi.org/10.18551/rjoas.2018-06.37

\title{
THE IMPLEMENTATION OF COMMODITY AND SERVICE PROCUREMENT BY VILLAGES IN SIDOARJO REGENCY
}

\author{
Yulianowarso Ronny \\ Department of Law Science and Development, Post-graduate School, \\ Airlangga University, Indonesia \\ E-mail: ronny juliano@yahoo.co.id
}

\begin{abstract}
Law \#6 of 2014 on Villages, furthermore referred to as the Village Law, is enacted effectively in 2015. This law covers, among others, the Status and Types of Villages, Village Arrangement, Village Authority, Village Governance, Village Roles and Villages and Rights Village, Finance and Village Assets, Rural Development, and Rural Area Development. The law states that villages are domiciled in the district / municipal territory consisting of Desa and Desa Adat or in accordance with the applicable mention in the local area. In order to organize the life of the nation, the government is required to promote the general welfare of the social justice for all of Indonesian. To achieve this, the government is obliged to provide for the people in various forms of goods, services, and infrastructure development. In addition, the government, in the implementation of government needs also goods services, for it needs of goods and services procurement. With this research shows that the authority of villages in implementing the procurement of goods and services aims to realize good governance in order to ensure the village administration is organized in accordance with the provisions of applicable legislation.
\end{abstract}

\section{KEY WORDS}

Goods, services, procurement, authority, village.

The administration of commodity and service procurement is the most crucial as it attracts many problems in price fixing, tender winning, the plaint and complaint. The procurement in village is better when it uses self management method. Because, the budget of village will be used to improve the village itself, it needs the contribution from people in it. For example, infrastructure development must use the procedure of PNPM or mutual cooperation. The price bargaining must follow the fixed price published by higher government such as City or regency, the different price may be found in shipping cost. The standard price list should be conducted in e-catalogue form by Commodity and service procurement council (LKPP). If the procurement in villages is occurred by tendering method, there will be many possibilities for the government to deceive the process. The deceiving act is very fragile among apparatus as, according to Priesident Decision number 54 of 2010, they never receive tendering workshop. Because, the workshop would consume much time and money. This problem makes the private sector to use in such illegal way to make them win and take over the project.

The procurement administration which is funded by APBD of villages must follow the principle of efficiency, effectiveness, transperancy, society priority, mutual cooperation, accountability and must be able to adapat with local culture. The principles must be followed to establish good commodity and service procurement in village level for more advanced development.

\section{METHODS OF RESEARCH}

Legal research is the process of finding the rule of law, legal principles, and legal doctrines to address legal issues faced. This is in accordance with the prescriptive character of jurisprudence. Different with research carried out in descriptive scientific knowledge test the truth whether there is a fact caused by a factor Certainly, legal research is conducted to 
generate arguments, theories, or new concepts as prescriptions in solving problems encountered on a descriptive scientific answer the expected answer is true or false, the expected answer in legal research is right, appropriate, inappropriate, or wrong.

Associated with this legal research there are two approaches used by the authors are:

a. The statutory approach, namely an approach using legislation and regulation. The legislation approach is done with reviewing all laws and regulations which arrangement relates to Procurement Implementation Goods and services.

b. A conceptual approach is a approach by trying to build a concept that will used as a reference in the study by moving from developing views and doctrines in the science of law. By studying views and doctrines the author can find ideas that can give legal notions, legal concepts, and the principles of law, legal principles relevant to the legal issues faced.

\section{RESULTS AND DISCUSSION}

Commodity and Service Procurement in Village. The commodity and service procurement, literally, is an act of users to obtain or realise the commodity or service by using controlled process and method to reach a deal in price, time, and etc. in order to realise the definition of procurement, both users and provider must pegged on the philosophy of procurement, act in ethics and norms of local procurement regulation, and follow the principles of method and process of legal procurement.

A good system of commodity and service procurement is a procurement which follows and implements the principles of good governance, support the effectiveness and efficiency of public expense, and the management of three pillars of behaviours (Government, Private sector, and Society). Thus, the good procurement will be in line with good governance.

In reformation era, the government struggle to realise a transparent and democratic state. One of the programs is by improving and optimising public service towards society through policies/regulations which must be effective, efficient, and able to represent the transparency and democratic state. Moreover, it is mandatory for government to provide and distribute information to society as stated in Law number 14 of 2008 about the public transparency which the vision of the transparency is to realise a good governance which are effective, efficient, accountable and responsible. As stated in article 3 alphabet C Law number 14 of 2008 about public transparency, State Gazette Number 4846 of 2008.

The law also states that everyone has a right to gain public information based on the regulation of the corresponding law. As stated in article 4 act 1 Law number 14 of 2008 about Public Information Transparency. The word transparency means a big chance for public to access the information towards governance program process. Meanwhile the efficiency means any actions that shorten the bureaucracy process of public service. Government as civil servant must provide a professional and maximum duty to realise good governance principle and implement clean governance.

Because of the problem, a new way of procurement is invented; it is electronic procurement of e-procurement. The regulation details are stated in President Law number 8 of 2006 about the fourth amendment of president law number 80 of 2003 about the instruction of commodity and service procurement. E-procurement started in 2007 with help of procurement council (LKPP). As stated before, the legal basis of LKPP establishment is stated in president decision number 106 of 20067 about the procurement of commodity and service council. E-procurement uses website and internet to offer the tenders towards third parties.

Electronic procurement has started their campaign as law number 11 of 2008 about electronic transaction information; the law allow wide and vast options legally. Eprocurement, as information system, is a data fusion, the artificial intelligent and the human who obtain and sent the information. The purposes of e-procurement are as follow: to improve transparency and accountability; to improve market access through fair competition; to fix the efficiency of conventional procurement; to support audit and monitoring process; to provide real time information. 
The implementation of e-procurement will help the relation between private sector, government, and the society become easier and faster. Moreover, the electronic procurement, automatically, will minimise the act of deception who may break the rule and result in society disadvantageous. In one hand, the electronic procurement could be supported with e-purchasing.

Even though e-procurement uses internet as media between both parties, it does not mean that the agreement between offeror and offeree is occurred on it. Paperless transaction is not an option for e-procurement. Because, not only entering data through website but the efferor is also need to upload some legal documents in the form of printed documents to the offeree. The deal is rached when the letter of agreement or memorandum of understanding states that the corresponding offeror win to do the project. In other words, e-procurement still prefer paper transaction to paperless one. Thus, the law is still worked for e-procurement.

For Corruption Eradication Commission (KPK), e-procurement is ultimate weapon to help them to trace and watch project of state. The state project is one of biggest project that would consume lot amount of money. That is why, any efficiency to prevent corruption would help state to minimise some financial lost. By publishing president law number 54 of 2010 as amendment of law number 80 of 2003 about commodity and service procurement by LKPP. In article 111 number 54 of 2010, it regulates the establishment of e-procurement (LPSE) to support LKPP procuring state needs.

The implementation of e-procurement is one of national program for the realization of a clean and corruption-free government. Where it will be through the program all government agencies both central and blood apply e-procurement in the procurement of goods / services. E-procurement offers the widest opportunity for improvement in cost and productivity. Therefore e-procurement is one of the most effective ways to improve management, either directly or indirectly, in the disbursement of the source of purchase. As a result, eprocurement will increase the key to success in improving future competitiveness.

Commodity/Service Procurement Aspects. Procurement initially began with the sale and purchase of goods in the market. The method or method of procurement of commodities and services in transactions is done by bargaining directly between the buyer (user) and the seller (provider of goods), including when the price agreement has been reached, the transaction process is also directly done. The process is not supported by the purchase, payment and receipt of goods. In its development into the sale and purchase of the term of payment, accompanied by documents of responsibility between the buyer and seller. The large number and types of items to be purchased take a long time if you have to bargain. Usually the user lists the amount and type of items to be purchased in writing. It is then submitted to the supplier to offer in writing anyway. The list of items that are written in writing is the origin of the purchase documents. While the price offer made in writing is the origin of the offer document. The next development, the user submits a list of items to be purchased not only to one, but to some providers of goods. Through their offerings, users can choose the cheapest price offer. That way is the forerunner of procurement of goods by auction. Procurement of goods is not limited to tangible goods, but also intangible goods. Intangible goods in general are services. For example health services, education services, consultancy services, supervision services, management services and so on.

From state administration law perspective, the procedure of commodity and service procurement is divided into two major laws. According to Prajudi Atmosudirjo, the two administration law are the law that regulates and created by the law who controls authority responsibility of state apparatuses.

The local autonomy of government duty is to fulfil the need of its people wther it is in form of commodity needs or services. The government, to do its duty, also needs some commodities and services. The commodity and service procurement of local government covers all contracts between local government (local institution, local state company) and even the private company.

Village Budget Allocation. Law number 6 of 2014 mention several policies, they are the definition, authority, right and duty, and the village financial status. In accordance with village 
financial, in this case is village budget, Village Ministry Law, Remote Area Development, and transmigration number 5 of 2015 about priority of village budget expense of 2015 states that the definition of village budget is a budget came from National Expense and Income Budget which is allocated for village and transferred through City/Regency Expense and Income Budget to facilitate governance, infrastructure development, socialization, and society empowerment. The simplified version is a budget which is run by village allocated and expensed through Village Expense and Income Budget (APBDes).

The village income comes from these points below: the village pure incomes are business result, asset result, self-contribution and participation, mutual cooperation, and etc; State Income and Expense allocation; Gained from part of taxes and City/Regency retribution; balance budget from City/Regency; financial aid from Province, City/Regency Income and Expense Budget; financial grant or donations from unbounded third parties, etc.

Regent/Mayor Regulation about Procurement by Village. In head of LKPP regulation number 13 of 2013, it instructs that the procurement of commodity or service in villages must use APBDes, crawled by Regent/Mayor Regulation, but still in line with head of LKPP regulation. Regent/Mayor must able to provide the result of program. From that responsibility, all Regent/Mayor must publish a regulation concerning commodity/service procurement in their area. But, there is no more regulation about procurement regulation until 2015, there are few numbers of places who conduct such regulation.

As a result, the government publish regulation of LKPP head number 22 of 2015 about amendment of LKPP head regulation number 13 of 2013 about commodity/service procurement in villages. Generally, this law tell us that the village who does not possess procurement regulation from its Regency/City, the instruction will be handed and followed LKPP Head regulation or follow the village procurement polices as long as it does not harm local norms and against LKPP Head current regulation.

Some local government had published their regent/mayor regulation about procurement. Unfortunately, the details are too general; they are not yer practical and operational details. There are several details that need to be revised to make it easier and more practical. Moreover, these details had become questions among politicians, the details are:

1. The number of program implementer team (TPK) is not firmly stated. In LKPP regulation, it states that a village could have more than one TPK; the number of team is decided by current situation and the job description that should be finished. Regent/mayor could determine the number of the team or they just leave the decision to the village based on their financial condition.

2. In the other hand, the Regent/mayor regulation must provide the details of the payment for these TPK crews. The detail must cover the amount of money they could received as their right or a certain money that they must not accept as present. In this case, it is the head of village, in some area, the head of village is prohibited to be part of TKP team, but others would allow it.

3. The regulation must assume the fixed price list that will be used as standard in their procurement are. Because, every districts had its own unique within the geographic condition. If the priced is fixed, the budget arrangement will be easier to determine which commodity is appropriate for the village.

4. E-catalogue is an option to arrange the budget if standardised price is not yet determined by the government. But, it is just as reference of the price, the procurement does not require e-catalogue. Because, e-catalogue would confuse TPK team if the system of fixed price is not provided within e-catalogue.

5. If the government is unable to do the project by itself, it could use the help of third parties for consultation purposes. But, the government already had Village Assistance Team (TAD) to solve such problem. That is why, more workshop and training must be applied to these apparatures. TAD team was established and taken oath by Regent/Mayor to be responsible in procurement. It must provide the details of their SOP within its function.

6. Nowadays, head of sub-district role is consolidated, although not as the Head of Region again, because the sub-district consists of several villages, it is necessary to 
delegate the Regent/Mayor to the sub-district head in terms of supervising the procurement in the village. This oversight instrument should also be contained in the Regents/Mayors Regulations, so that, sub-district head can able to use its authority if he/she found things that deviate in accordance with the provisions in the procurement process of goods / services. The involvement of the Regional Inspectorate is possible, but the Inspectorate's supervision serves to thoroughly oversee the implementation of village budget arrangement and the administration of the village administration or other special matters. It may be that the results of supervision by the sub-district head are forwarded or reported to the Regent/Mayor with a copy of the Regional Inspectorate.

7. The procurement by villages does not use what we called as Self-Assumed Price (HPS). That is why the arrangement of budget must be based of the closest market within its current situation. Thus, the arrangement of procurement price list is the representation of villages' current financial status. But, if the fixed prices are already provided and legalised by Regency/City level, villages must obey and follow the price. The movement of price in market is very unpredictable, if the price change while implementing the arrangement; the price must follow the most up to-date price to achieve the efficiency and effectiveness principles of procurement.

8. The Regent/Mayor Regulation must provide templates and formats for TPK team such as offering letter template and purchasing letter to referrer, memorandum of understanding, acceptance certificate between TPK and Private sector and result of acceptance letter among them. The letters and templates could be printed and distributed by city or regency government to the villages, but if the people could not afford, they could just write it down in piece of paper.

9. Article 31 Ministry of Home Affairs number 113 of 2014 about management of village budget states that the treasurer of villages must able to provide taxes. It is mandatory to collect taxes and transferred them to state bank account by procedure stated in law. The regulation and instruction is very clear that the treasurer must send them. That is why the treasurer must register their self to obtain tax identification number. That is why the regency or city regulation must restate this law firmly.

Self-Management Implementation. The self management of procurement by villages is the most interested thing in recent years, the higher budget that each village gets every year even draws more attention among societies. The ministry of home affairs and villages state that self management becomes priority in commodity and service procurement.

The method of self management procurement of commodity and service is a result of two principles fusion from five principles as stated and regulated in article 3 of Regent Regulation number 54 of 2014 , the principles are:

a. Society must able to learn how to manage their village by studying from implementation of commodity and service procurement.

b. Mutual cooperation is a free help from societies to support the development of their village.

These two principles would create different procurement of commodity and service established by village and the procurement which is commenced by Ministry/Institution/Local Government/Institution.

Stated in Sidoarjo Regent Regulation article 15 act (1) number 54 of 2014, it states "based on the principle, any procurement must be established by self management by using local material optimally, with the help of the people, the procurement will open new job vacancies and social empowerment"

For Society, the investment, in terms of economic aspects, will provide opportunities to increase revenue. So, the impact of socio-economic aspects of the implementation of procurement in the village is very large for the life of the village community both from the positive side and the side problems that will arise in the future. Local governments should continue to assume potential problems that will probably occur, they also must conduct a review/revision as the results Village Conference, Sub-District, and District, for example delivered the cycle of APBDes, village finance signs, the management of commodity/service in the village in practical ways which is easily understood by the village community. This 
must be achieved to monitor and evaluate each stage of implementation of the APBDes itself. Particularly, in the implementation of procurement of commodity/service in the village, for regions that have issued Regents/Mayors Regulation on Procurement Procedure of commodity/service in the Village or have not yet issued the regulation, to immediately conduct assessment and determination related to the procurement of commodity/service in the village by - a practical way that is easily understood by local villagers. Taking into account the social and cultural conditions and geography of the local community so that the rules made can be implemented.

Commodity/Service Procurement in Village through Private Provider. By using procurement provider aid, there are two condition that may be face by both parties, they are:

a. the procurement for less than Rp. 50.000.000,- in this procurement, the implementation is lead by head of TPK. The procedure started with negotiation among two parties by face to face meeting and proceeds to payment step. There are no more documents from both provider and government but payment bill and receipt. Most of the budget of village is spent in this condition.

b. The procurement which is more than Rp. 50.000.000,-there are several phases as procedure for this condition, as follow:

- TPK invite two written offering letter from two providers which is bale to support local village development. It must be attached with the details of commodities or services, volumes, and the specification of the commodities or services.

- The provider must bring written offering letter within details of the commodities or services and the pricelist.

- TPK examine the specification of the technical procedures from the provider who sent the offering letter.

- TPK must be able to obtain cheaper price in bargaining process

- The result of negotiation must be mentioned in agreement sheet of both.

- The final result is handed out to head of village.

The Economic Aspect by Using Procurement Provider Aid. The inability of village governance to implement all procurement by itself forced the government to obtain aid from the private sector. There are several procurements that aided by private sector such as electronic devices, furniture, office stationery and etc.

The construction project is one of procurement that government must get aid from provider. Because, the complex building and high skill architect need more work and time to be completed

Generally, people assume that procurement providers are big tender company who must be in a group. In reality, the provider must not always be from company, it can also come from individual private sector.

Government will gain advantage if the procedure and range of the procurement are simplified. Because, the level of this procurement is on village level which is completely different from Ministry/Institution/Village Council/and another institution. There is a significance principle such as "mutual cooperation" and "Society Empowerment" which replace the principle of competitive, fair and not discriminative it is appropriate for government spending in the scope of Village Government.

The procurement is very simple in village level. For example, if government tend to make an event or a little limited meeting, they could use local sources commodities to procre their need such as food and beverages. They could buy it on a local streetfood as long as the quality is good. by buying the food and average, the village governance has used its state budget for their activity. it is a simple example of individual procurement of commodities in villages.

The simple procurement also works on office stationery. The government could just buy it on a local store to but the office needs. But, if they cannot find tools on their own village, they could buy it on another village's store. For example, if they could not find motorcycle dealer in their village, they are allowed to buy it on another village as it is impossible for their own village to provide it. 
Unfortunately, for complex building such as big bridge, TPK must offer the procurement to the private providers. It is top priority for the government to find local provider that still belongs to the source of the village. But, the advantages of using private sector may not be obtained especially for society, because of these following reasons as follow:

a. The labours are not local people

The providers commonly have permanent workers from different places that are willing to be paid lesser than local labours.

b. The materials will not use local resources.

The providers already had permanent colleagues to buy materials which enable them to control their financial circulation

Beside of that, the building will be the only advantage gained from construction procurement by the providers as it is finished.

\section{CONCLUSION AND SUGGESTIONS}

The implementation of commodities and services procurement is started from direct transactions in market, it develops into instalment payment method, the next development is by using contract between two parties, and the last evolution is by using auction process. In auction process, there are many people who include on the process; the process must possess norms and principles to control these actors. The procurement in villages give positive impacts compared with auction held by any higher institution. Because, the villages have "mutual cooperation" and "Society Empowerment" which replace the principle of competitive, fair and equity, it is appropriate for government spending in the scope of Village Government.

There must be revision accordance with Regent regulation that controls procurement policies of commodities and service especially in Sidoarjo Regency as the current regulation does not appropriate with Village Financial Administration.

\section{REFERENCES}

1. The 1945 Constitution of Republic Of Indonesia.

2. Law \#23 of 2014 about Local Government.

3. Law \#17 of 2003 about Financial State.

4. Law \#1 of 2004 about State Treasury.

5. Law \#6 of 2014 about Local Village.

6. Law \#12 of 2011 about Establishment of Constitution.

7. Government Regulation \#38 of 2007 about the division of Governance between Governments, Province Government and Local Government of Regency/City.

8. Government Regulation \#43 of 2014 about Implementation of Law \#6 of 2014 about Village.

9. Government Regulation \#60 of 2014 about Village Treasury from APBN.

10. Government Regulation \#54 of 2010 jo about President Regulation \#70 of 2012 about Commodities/Service Procurement By Government.

11. President Regulation \#70 of 2012 about second amendment of President Regulation \#54 Of 2010 About Commodity/Service Procurement by Government.

12. Head of LKPP regulation \#13 of 2013 about the procedure of Commodities/Service Procurement in Village.

13. Sidoarjo Regent Regulation \#54 of 2014 about Commodities/Service Procurement in Village.

14. Adrizan Sutedi, Aspek Hukum Pengadaan Barang dan Jasa dan Berbagai Permasalahannya. Jakarta: Sinar Grafika, 2010.

15. Kebijakan Pengadaan Barang dan Jasa dan Pembaruannya, dalam Aspek Hukum Pengadaan Barang dan Jasa dan Berbagai Permasalahannya, Sinar Grafika, 2012.

16. Amiruddin, Korupsi dalam Pengadaan Barang dan Jasa. Genta Publishing, 2010.

17. Prajudi Atmosudirjo, Hukum Administrasi Negara, Ghalia, Indonesia, Jakarta, 1981. 